\title{
Assessing the effect of Faidherbia albida based land use systems on barley yield at field and regional scale in the highlands of Tigray, Northern Ethiopia
}

\author{
Kiros M. Hadgu • Lammert Kooistra • \\ Walter A. H. Rossing - Ariena H. C. van Bruggen
}

Received: 19 February 2009 / Accepted: 7 July 2009 /Published online: 25 July 2009

(C) The Author(s) 2009. This article is published with open access at Springerlink.com

\begin{abstract}
Implications of changes in traditional Faidherbia albida based land use systems on productivity were investigated in Tigray, northern Ethiopia. The relation between F. albida based-land use systems and crop productivity was explored in 77 fields and 81 farms at field and regional scales, respectively. Barley yield and soil fertility increased when field locations were closer to a $F$. albida trunk in the F. albida alone (AA) and F. albida + livestock (AL) land use systems. However, the F. albida + Eucalyptus camaldulensis (AE) land use system showed a decreasing trend in barley yield and soil fertility as distance from a $F$. albida trunk decreased. At regional scales, higher F. albida tree density per farm and sparsely cultivated land use types were associated with increased potential ecosystem services (barley yield). This study suggests that local
\end{abstract}

K. M. Hadgu

Faculty of Natural Resources and Agriculture, Mekelle University, P.O. Box 231,

Mekelle, Tigray, Ethiopia

K. M. Hadgu • W. A. H. Rossing • A. H. C. van Bruggen Biological Farming Systems, Department of Plant Sciences, Wageningen University,

Marijkeweg 22,

6709 PG Wageningen, The Netherlands

K. M. Hadgu $\cdot$ L. Kooistra $(\bowtie)$

Laboratory for Geo-information and Remote Sensing,

Wageningen University,

Droevendaalse Steeg 3,

6708 PB Wageningen, The Netherlands

e-mail: lammert.kooistra@wur.nl

A. H. C. van Bruggen

Department of Plant Pathology, University of Florida,

1453 Fifield Hall, P.O. Box 110680, Gainesville, FL 32611-0680,

USA biodiversity components (e.g. F. albida trees) can increase crop yield and soil fertility significantly when grown within and around farm lands. This study contributes to the knowledge on agricultural productivity enhancement by developing an approach to scaling up from farm to regional level.

Keywords Faidherbia albida . Ecosystem-service . Land-use $\cdot$ Scaling $\cdot$ Barley productivity

\section{Introduction}

Ensuring sustainable agricultural productivity to reduce poverty, while minimizing environmental degradation (e.g., biodiversity loss) is one of the main goals of the UN Millennium Project (Sachs and McArthur 2005; UN Millennium Project 2005). However, biodiversity and ecosystem functions are declining because of increased demand for food production and inappropriate policies for the use of natural resources (MEA 2003). The consequence of this could be severe environmental degradation and low agricultural productivity, especially in sub-Saharan African countries, which are facing food insecurity problems. Soil erosion and soil fertility depletion caused by humaninduced and natural drivers are among the most important factors contributing to the deterioration of agricultural productivity in sub-Saharan Africa (Sanchez 2002). As a response to this, approaches have been developed that promote best use of science and technology to increase agricultural productivity, especially in Sub-Saharan Africa, through the use of inorganic fertilizer and adoption of market-oriented agricultural productivity strategies (IAC 2004). A recent report by IAASTD (2008) proposed ways of increasing agricultural productivity by taking into 
account the diversified bio-physical resources of smallscale farms, usually negatively affected by environmental changes, and where the potential for improved agricultural productivity is low. As addressed in this paper, sustainable increase in agricultural productivity requires an approach which reverses the current negative influence of agriculture on biodiversity (MEA 2005).

Various authors have pointed out the potential of tree-based cropping systems for increasing crop productivity in arid and nutrient-deficient smallholder farming systems (Paoletti et al. 1992; Ong and Leakey 1999; Rao and Mathuva 2000). However, tree-crop interactions can have both positive and negative effects on the structure and functioning of the agroecosystem (Ong 1995; García-Barrios and Ong 2004). Trees can compete with crops for light, water and nutrients and decrease crop yield when density and size of trees is high (Akonde et al. 1996; Cannell et al. 1996; Miller and Pallardy 2001; García-Barrios 2003). Trees often affect soil moisture content, either increasing (Caldwell and Richards 1989; Dawson 1993) or decreasing it (Smith et al. 1999; Odhiambo et al. 2001), and thereby influencing nutrient transport to crop roots and root growth (Radersma et al. 2004). Although trees can increase the potential soil water-holding capacity (soil's ability to store water), they have also negative effects on the actual water volume (water present when the soil is at field capacity: approximate water content at which the internal drainage of water through the soil profile due to gravity becomes negligible) available in the tree-crop-soil system. For example, as much as $50 \%$ of rainfall intercepted by the canopy can evaporate annually without reaching the soil when tree density is high (Ong et al. 1996). However, trees and crops differ greatly in size, life form, phenology and capacity to capture and use efficiently above-and belowground resources (Goldberg 1990). Thus, their intra-and inter-specific competition can differ strongly. A tree may modify or improve growth of another tree or crop by changing the bio-physical conditions and thus establish a better potential environment for the latter (Hunter and Aarssen 1988; Rhoades 1997). Trees can increase system productivity by reducing nutrient losses through leaching into the subsoil, reducing soil erosion, providing protection from wind erosion (Rao et al. 1998), reducing weed populations, enhancing resistance to cyclic environmental changes, enhancing efficient utilization and recycling of resources (Liebman and Gallandt 1997; Ong et al. 1996) and increasing available nutrients for crops by root exudates or rhizosphere effects (Radersma and Grierson 2004).

As in other developing countries, smallholder farms in Ethiopia are under pressure as a result of intensification and agro-ecosystem simplification (Worede 1991 and 1997). This could become a serious threat to the sustainability of agricultural productivity with negative consequences such as severe soil erosion, fertility decline and water scarcity
(Hurni 1993; Shiferaw and Holden 2000; Dejene 2003). Within the Tigray region in Northern Ethiopia, farmers take care of naturally growing Acacia albida Del. (Syn. Faiderbhia albida (Del.) A Chev.) trees in and around their farm land in order to improve soil fertility and increase crop yields. This tree species has a special phenology as it sheds its leaves during the rainy season and keeps them during the dry season, i.e. from October to June. Thus F. albida sheds its leaves when ploughing begins and hardly competes for light and water during the growing season of the crop. Furthermore, F. albida trees fix nitrogen and provide nitrogenous and other nutrients to a crop when their leaves are incorporated into the soil (Rao et al. 1998). In addition, the trees serve as fence and fuel, and provide fodder and shade to the livestock. This means that the presence of $F$. albida within the traditional smallholder farming system provides ecosystem services which can be categorized as provisioning services (including food production), regulating services (e.g. climate regulation, nutrient cycling, soil conservation), and supporting services (e.g. biodiversity) (Costanza et al. 1997; Daily 1997; MEA 2003). Also, manure from livestock fed fallen leaves of $F$. albida is commonly used as a fertiliser in farming systems in Ethiopia (Tekalign et al. 1991).

Several studies (Poschen 1986; Kamara and Haque 1992; Asfaw and Ågren 2007) have shown the positive effect of $F$. albida trees on yields of different crops (e.g., maize and sorghum) of traditional smallholder farming systems in Ethiopia. These studies compared, at field scale, yields under $F$. albida with yields at greater distances from the tree. However, no information was available in these studies on the influence of $F$. albida on barley productivity at increasing distances from a tree and under different $F$. albida based land use systems. Also, there is lack of integration of results obtained at different spatial scales (e.g., field, farm and regional scales). Land use intensification in Ethiopia has included the use of inorganic fertilizer and planting of Eucalyptus species for fuel wood and house construction. This process causes a shift away from the traditional $F$. albida based farming practices including livestock because Eucalyptus grows quickly and is used as a means of income, especially by farmers close to towns, markets and roads. The agricultural intensification process affects biodiversity at the regional scale (Hadgu et al. 2008a) and could also influence F. albida density and yield benefits derived from the tree.

The objective of this paper is to investigate implications of changes in traditional $F$. albida based land use systems on productivity for the Tigray region in Northern Ethiopia. Productivity, as used in this study, is measured as barley yield. Barley is one of the most important crops in the study area. The hypotheses addressed in this study are: (i) closer to an F. albida tree and at high F. albida tree density, barley yield and soil properties (total $\mathrm{N}$, available $\mathrm{P}$, soil organic 
matter, $\mathrm{pH}$ and soil moisture) are affected positively and (ii) F. albida based land use systems are associated with low intensity agricultural land use types. The study may, therefore, assist policy development on food security, particularly with respect to the enhancement of agricultural productivity in resource poor smallholder farmers in the tropics.

\section{Materials and methods}

Study location

The study was undertaken in the highlands of Tigray in Northern Ethiopia (Fig. 1). The study region $\left(13^{0} 85^{\prime}-\right.$ $14^{0} 00^{\prime} \mathrm{N}$ and $38^{\circ} 45^{\prime}-39^{\circ} 05^{\prime} \mathrm{E}$ ) is located South-East of the town of Adwa and covers an area of about 30 by $40 \mathrm{~km}$ at an elevation of $1300-2800$ metres above sea level (m.a.s.l). The climate of the area is semi-arid, with two rainy seasons, the main season starting in late June and lasting until September, and a minor season between March and April. The average annual rainfall ranges from $740 \mathrm{~mm}$ at $1500 \mathrm{~m}$ to $900 \mathrm{~mm}$ at $2000 \mathrm{~m}$ (Deurloo and Haileselassie 1994). Wide variation in rainfall from year to year is characteristic for the area. Soils are categorized as Cambisols, Fluvisols, Xerosols, Vertisols and Luvisols (Sarraute and Vonder 1994). The study region is one of the most densely populated areas (ranging between 30 and 740 inhabitants $/ \mathrm{km}^{2}$ ) in Ethiopia (Feoli et al. 2002). Land use within the area consists of four dominant classes (Hadgu et al. 2008a): woodland, shrub land (stands of shrubs not exceeding $3 \mathrm{~m}$ in height and with a canopy cover of more than $30 \%$ ), scrubland (strata of shrubs and grasses or herbs and with a canopy cover of less than $30 \%$ ) and agriculture. Mixed crop-livestock, smallholder farming is typical for the study area. Within this farming system different degrees of agricultural intensification can be identified ranging from sparsely cultivated (Scu) to intensively cultivated (Icu) areas (Table 1) (Hadgu et al. 2008a). F. albida trees are present throughout the region with varying densities (Fig. 2) mainly remnants of natural land cover types (e.g., woodland, shrub land).

\section{Research strategy}

The relation between biodiversity and productivity of the smallholder systems within the study region was assessed at the field scale and extrapolated to the regional scale based on the land use classification. To investigate the contribution of F. albida based land use systems on barley yield productivity, we distinguished measured field data and farm survey data which correspond to field scale and regional scale, respectively.

Site selection for field data acquisition was achieved through identification of the sub-region first and then a site with good examples of $F$. albida tree based farming practices. In selecting the sub-region (Fig. 1b) with good F. albida tree based farming practices, a tour was made of the whole study region together with extension agents. Actual information on the farming practices of the region were collected from farmers $(n=38)$ by interviewing key informants, group discussions and joint field excursions to select key areas with good examples of $F$. albida farming systems. In addition, topographic maps coupled with
Fig. 1 Location of study area: a region and $\mathbf{b}$ sub-region with field scale sample points in Tigray, Northern Ethiopia

\section{(a) Study region}

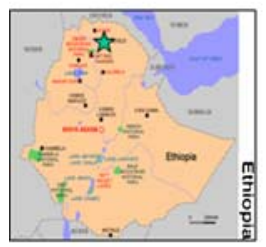

(b) Sub-region

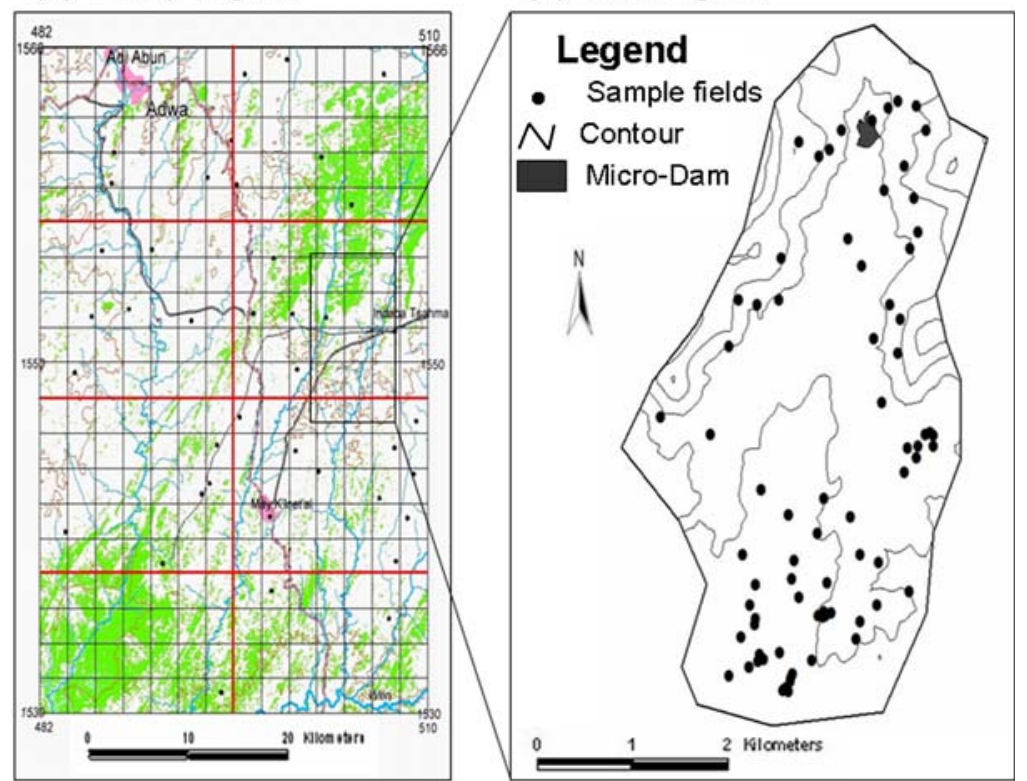


Table 1 Agricultural land use types for the study area (region and sub-region) in Tigray, Northern Ethiopia

\begin{tabular}{ll}
\hline Land use type & Description \\
\hline $\begin{array}{l}\text { Sparsely Cultivated } \\
\text { land (SCu) }\end{array}$ & $\begin{array}{c}\text { Between } 20 \text { and } 40 \% \text { of the mapping unit is } \\
\text { under cultivation while the remaining area } \\
\text { is covered by trees, shrubs or herbs. }\end{array}$ \\
$\begin{array}{c}\text { Moderately cultivated } \\
\text { land (MCu) }\end{array}$ & $\begin{array}{l}\text { Between } 40 \text { and } 70 \% \text { of the mapping unit is } \\
\text { under cultivation while the remaining area } \\
\text { is covered by trees, shrubs or herbs. }\end{array}$ \\
$\begin{array}{l}\text { Intensively Cultivated } \\
\text { Oner } 70 \% \text { of the land is under cultivation } \\
\text { lanhile the remaining area is covered by } \\
\text { trees, shrubs or herbs. }\end{array}$ \\
\hline
\end{tabular}

farmers' sketches contributed to identifying the sub-region with $F$. albida farming systems. In the same sub-region, land use systems (LUS) with mature $F$. albida visited by livestock for shade and/or fodder and with mature $F$. albida growing adjacent to mature Eucalyptus camaldulensis were also identified. As a result, a sub-region (Fig. 1b) of approximately $6 \times 8 \mathrm{~km}$ was chosen for the field scale analysis $\left(14^{0} 05^{\prime}-14^{0} 10^{\prime} \mathrm{N}\right.$ and $\left.38^{0} 55^{\prime}-39^{0} 05^{\prime} \mathrm{E}\right)$. This subregion is located in the North-Eastern part of the study region (Fig. 1b) and has an elevation between 2000 and $2400 \mathrm{~m}$.
Field measurements

Based on farmers' information with regard to the presence of $F$. albida trees and land use type, 77 barley fields were selected within this sub-region (Fig. 1b). Within each field, measurements of soils and barley yield were made around one mature $F$. albida tree separated from the nearest mature $F$. albida tree by at least $50 \mathrm{~m}$ to establish the effect of an individual $F$. albida tree on crop and soil characteristics. In the selected fields, soil and barley yield samples were collected at 1,25 and $50 \mathrm{~m}$ from a solitary $F$. albida tree to investigate if locations close to an F. albida trunk benefitted barley yields. The slope of each field was measured by clinometers. Land use types (Table 1) for the sampled fields in the sub-region were classified using remote sensing and the field based land use classifications of Hadgu et al. (2008a).

The relationship between barley yield and soil properties (total $\mathrm{N}$, organic matter $[\mathrm{OM}]$, available $\mathrm{P}$, soil moisture and soil $\mathrm{pH}$ ) at different distances from an F. albida tree within a field was investigated for all 77 locations. We assumed that nutrient availability can be increased in agricultural fields by transport of nutrients from the subsoil and $\mathrm{N}$-fixation by trees, and by manuring (animal droppings) from livestock. Therefore, sampling
Fig. 2 Different Faidherbia albida land use systems in the Tigray sub-region in Northern Ethiopia with $F$. albida alone (AA), F. albida and livestock (AL) and F. albida and Eucalyptus (AE)
AA low density

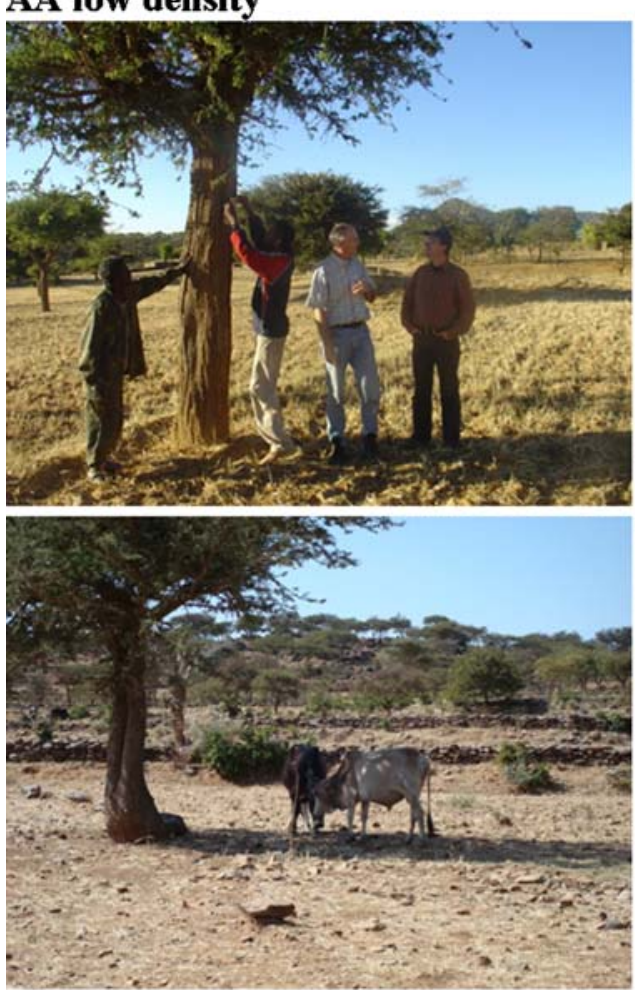

AL

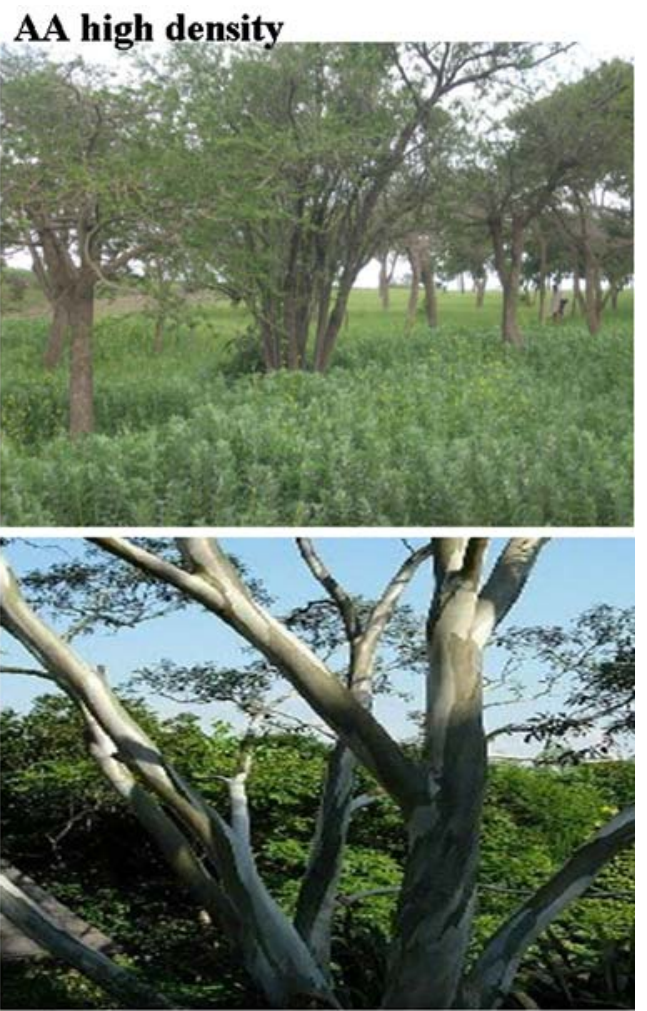

$\mathbf{A E}$ 
occurred in strata corresponding to three different $F$. albida land use systems (Fig. 2):

1. F. albida alone (AA): only F. albida is present along field boundaries or within fields without interference of other tree species or livestock;

2. F. albida and livestock (AL): the presence of F. albida is combined with livestock which use the tree for shading and/or fodder;

3. F. albida and Eucalyptus camaldulensis (AE): F. albida growing adjacent to Eucalyptus camaldulensis in a field.

Within the sub-region, fields with AA and AL land use systems were located on more gentle slopes and at lower altitudes than fields with the AE land use system. Most fields with an $\mathrm{AE}$ land use system were located close to a micro-dam and were irrigated. In addition, inorganic fertilizer was applied to these fields, particularly in fields located in the Northern part of the sub-region (Fig. 1b). In contrast, irrigation and inorganic fertilizers were not applied to fields far from the micro-dams; most of them located in the Southern part of the sub-region.

For each of the 77 selected fields, barley and soil samples were collected at $1 \mathrm{~m}, 25 \mathrm{~m}$ and $50 \mathrm{~m}$ from the $F$. albida trunk. As a result, sampling of the fields was performed in a split plot design with the three land use systems (AA, AL and $\mathrm{AE})$ as a main-plot and the distances from the center of $F$. albida trunk (1 m, $25 \mathrm{~m}$ and $50 \mathrm{~m})$ as sub-plot. The number of sampled fields was almost equally divided over the three land use systems: AA ( $n=23)$, AL $(n=27)$ and $\mathrm{AE}(n=27)$.

Barley samples were taken by harvesting all aboveground crop material within a $1 \times 1 \mathrm{~m}$ quadrant. Within this quadrant, soil samples were collected from the top $0-15 \mathrm{~cm}$ plough layer and stored in labeled and sealed plastic bags. Canopy characteristics of the F. albida trees were determined and their coordinates acquired using a hand-held GPS (Garmin eTrex Summit 2000). The sampled F. albida trees had a mean canopy width of $12.43 \mathrm{~m}( \pm \mathrm{SE} 0.57 \mathrm{~m})$, a height of $5.89 \mathrm{~m}( \pm \mathrm{SE} 0.09 \mathrm{~m})$ and a diameter at breast height (DBH) of $0.62 \mathrm{~m} \pm($ SE $0.07 \mathrm{~m})$.

The harvested barley crop material was oven-dried at $70^{\circ} \mathrm{C}$ for 48 hours and weighed to calculate the total dry biomass $\left(\mathrm{kg} \mathrm{ha}^{-1}\right)$. Grain was separated from the straw by threshing and grain yield $\left(\mathrm{kg} \mathrm{ha}^{-1}\right)$ was determined for each sample. Total barley biomass was well correlated with barley yield $\left(r^{2}\right.$ of 0.6$)$. Therefore, statistical analysis results will only be presented for barley yield.

Soil samples from the plough depth $(0-15 \mathrm{~cm})$ were collected, after removing the litter on the surface, and were incubated inside plastic bags to maintain soil moisture at constant levels (MoNRDEP 1990). The samples were transported to the laboratory inside the sealed bags and were analysed within 48 hours of field sampling. To determine total nitrogen content $(\%)$, organic matter content $(\%)$, available phosphorus $\left(\mathrm{mg} \cdot \mathrm{kg}^{-1}\right)$ and $\mathrm{pH}$ (in a 1:2.5 soil: solution extract with water), the soil samples were sieved through a $2 \mathrm{~mm}$ sieve, air dried and analyzed according to the methods described in MoNRDEP (1990). With regard to the soil moisture determination, the collected soil samples were weighted after removal from the sealed plastic bags. They were oven dried for 24 hours at $105^{\circ} \mathrm{C}$ and weighed again. The gravimetric soil moisture content was determined as the amount of water relative to the amount of wet soil. Total nitrogen content (\%) was determined using the Kjeldahl method. The Walkley and Black method was used to determine the organic matter content (\%) and available phosphorus (mg. $\mathrm{kg}^{-1}$ ) was determined by the Olsen method. Finally, the soil samples were analyzed for $\mathrm{pH}$ (in a 1:2.5 soil: solution extract with water) and soil moisture content. Data were log transformed before statistical analysis.

\section{Farm survey}

In an earlier study, 151 farms were selected within the complete study region (Fig. 1) from four sampling strata based on intensity of land use, natural vegetation and altitude derived from a Digital Elevation Model (DEM), aerial photographs and topographic maps. In each substratum, sample farms were selected randomly (Hadgu et al. 2009). Every farm, consisting of four fields on average which were mostly adjacent to one another, was surveyed in 2005 including interviews with farmers, and two to three transects were made across farmers' fields. For every farm, field locations were recorded using a hand held GPS and crops, farmer's estimates of their yield, tree and shrub species and general management in and around the sampled farms were recorded (Hadgu et al. 2009).

Of the full set of farms only farms with barley were taken into account in this study, resulting in a dataset of 81 farms. Barley yield was estimated at farm level based on farmers yield estimates. For the survey in 2005, no data were collected on soil characteristics or on yield as a function of distance from trees. For each farm, four categories of characteristics were derived from the results of the survey (categories 1 and 2) or from GIS analysis (categories 3 and 4):

1) livestock density: three classes of livestock density (number of cattle per farm household) were derived from the questionnaire of the 2005 farm survey (Hadgu et al. 2009): no livestock (NL), low livestock $\left(1-2 \mathrm{farm}^{-1} ; \mathrm{LL}\right)$ and high livestock $\left(>2 \mathrm{farm}^{-1} ; \mathrm{HL}\right)$;

2) inorganic fertilizer use: three classes of inorganic fertilizer use $\left(\mathrm{kg} \mathrm{ha}^{-1}\right)$ were derived from the questionnaire of the 2005 farm survey (Hadgu et al. 2009): no 
fertilizer (NF), low fertilizer use $\left(1-25 \mathrm{~kg} \mathrm{ha}^{-1}\right.$; LF) and high fertilizer use $\left(>25 \mathrm{~kg} \mathrm{ha}^{-1} ; \mathrm{HF}\right)$;

3) F. albida density: tree density was derived from the 2005 land use map of the study region (Hadgu et al. 2008a). High F. albida density (HA), medium F. albida density (MA) and low F. albida density (LA) were observed with more sparsely cultivated land, moderately cultivated land and intensively cultivated land, respectively;

4) presence of Eucalyptus camaldulensis: within the study region, presence of E. camaldulensis is largely associated with urban areas. Using a spatial buffer of $5 \mathrm{~km}$ around major towns in a GIS, farms within the buffer were categorized as having a E camaldulensis dominated land use (HE) whereas farms located outside the $5 \mathrm{~km}$ buffer were categorized as farms with low $E$. camaldulensis land use (LE).

Data analysis

To take into account fixed and random effects, a mixed model analysis (SAS 1999) was performed on the field scale data set to compare barley yields of different $F$. albida land use systems at various distances from the sampled F. albida tree. Similarly, a mixed model analysis was carried out on the soil characteristics, as dependent variables, of the F. albida land use systems at different distances from the F. albida trunk. Using the split-plot design, F. albida land use system (main plot) and distance from the center of the F. albida trunk (sub-plot) were considered as fixed effects. Field slope was treated as random effect but was found to be insignificant $(p>0.05)$. Type III sums of squares were computed in the test for fixed effects. Significance of fixed effects was tested using Wald's F-test. To evaluate which specific interactions between distance from the F. albida trunk and land use systems contributed significantly to barley yield, mean estimates from the mixed model output were presented separately. Multiple regression with forward selection (SAS 1999) was used to investigate the relationship between barley yield and soil properties.

The fields in which measurements were made, were classified into land use land cover (LULC) classes described for the area in a previous study (Hadgu et al. 2008a). A LULC map for 2005 was available which had been classified from Enhanced Landsat Thematic Mapper Plus (ETM+) satellite imagery using maximum likelihood classification. The LULC map was overlaid with the 77 field locations at $1 \mathrm{~m}$ distance from the center of a $F$. albida trunk and relations between LULC types and $F$. albida based land use systems at these points were analyzed. Field locations with positional inaccuracies $(n=7)$ were left out of the analysis. In addition, the field locations were overlaid with an elevation map derived from the Shuttle Radar Topographic Mission (SRTM) to relate F. albida based land use system to altitude. All spatial analysis procedures were carried out in ArcGIS 9.2 (ESRI, Redlands, CA, USA).

Using the data from the farm survey (81 farms), the relation between $F$. albida and barley yield was analyzed using Canonical Correspondence Analysis (CCA) in CANOCO 4.5 (Ter Braak and Smilauer. 2002) to explore the relationships between the response variable (barley yield) and explanatory variables (inorganic fertilizer use, livestock density, E. camaldulensis dominance and $F$. albida dominance). A Monte Carlo permutation test was used to reveal the effect of the explanatory variables on barley yield. As the survey samples were collected randomly, unrestricted permutations with a total of 499 permutations as recommended in the software (Ter Braak and Smilauer 2002) was performed. For the CCA analysis, the four explanatory variables were coded into dummy variables. In addition, three categories of farm Altitude: low (1300-1600 m.a.s.1), intermediate (1600 - 1900 m.a.s.1.) and high (>1900 m.a.s.l) were included as covariable.

To estimate added ecosystem service (in this case added barley yield), a simple spatial graphical analysis was carried out with three spatial density configurations of $F$. albida within 1 hectare of land, corresponding to low, moderate and high spatial $F$. albida tree densities. These three tree densities were assumed to correspond to intensively, moderately and sparsely cultivated land use types (Table 1). Starting from an average farm size of 1 ha with four adjacent fields, we assumed fields to consist of regular grids of trees, with trunks at $12 \mathrm{~m}$ distance. We calculated yield benefits from $F$. albida as the mean of the benefits at $1 \mathrm{~m}$ and at $25 \mathrm{~m}$ from the trunk in the AA land use system and applied this to circles of barley around each tree. The overall yield benefit or added ecosystem service for this idealized sparsely cultivated land use system (with a high density of trees) was calculated. Trees were then removed from the field at random, each tree reducing yield by a fixed amount equivalent to its area of influence, until the fields were cleared and only the edges contained trees (medium density of trees). Additional yield losses were calculated after further removal of trees down to trees just at the corners of the fields (low density) and no trees at all. Added ecosystem services (contributions to barley yield) were plotted versus tree density at different configurations.

\section{Results}

Productivity and land use systems at field scale

Barley yield was significantly affected by distance from the center of $F$. albida trunk (Dist) and by the interaction of 
distance and land use systems (Dist*Manag) (Table 2). Significantly higher barley yields $(p<0.05)$ were found at $1 \mathrm{~m}$ distance from the tree compared to yields at $25 \mathrm{~m}$ and $50 \mathrm{~m}$ for land use systems AA and AL (Table 3 and Fig. 3). In contrast, in the AE land use systems barley yields did not change significantly with distance from the tree although average yields were lowest under the tree (Table 3 and Fig. 3).

The effect of $F$. albida land use system and distance from $F$. albida trunk on soil properties is shown in Table 2. The interaction was significant for total $\mathrm{N}(P<0.05)$, available $\mathrm{P}(P<0.001)$, and soil moisture $(P<0.0001)$. Mean values of these soil properties decreased with distance from the tree for $\mathrm{AA}$ and $\mathrm{AL}$, and were more erratic for AE. Organic matter was significantly affected only by distance from the tree irrespective of $F$. albida based-land use system. For available $\mathrm{P}$, the interaction could clearly be attributed to high available $\mathrm{P}$ concentrations at $1 \mathrm{~m}$ from the tree in the $\mathrm{AL}$ land use system (Table 3). Soil moisture showed sharply decreasing trends with distance for $\mathrm{AA}$ and $\mathrm{AL}$, and increasing trends for $\mathrm{AE}$ (Table 3). Soil $\mathrm{pH}$ did not show any response to distance of F. albida-based land use system.

Stepwise regression analysis of barley yield on soil properties indicated that soil moisture significantly affected barley yield in the AA $(P<0.01)$ and the AL $(P<0.001)$ land use systems. In contrast, barley yield was not significantly related with other soil properties (Table 4).

The GIS analysis showed that land use systems AA and AL were mainly associated with sparsely cultivated and moderately cultivated land use classes, respectively (Figs. 4 and 5).
The AE land use system was associated with all three agricultural land uses types (sparsely cultivated, moderately cultivated and intensively cultivated). Most locations with AE land use system were also associated with the use of high yielding varieties and inorganic fertilizers, mainly in irrigated areas at an elevation of $2100-2200 \mathrm{~m}$ (Fig. 4b).

Productivity and farm characteristics at regional scale

Canonical correspondence analysis showed clear relations between barley productivity and farm characteristics (Fig. 6). The first axis of the ordination diagram represents mainly the tree densities of $F$. albida and E. camaldulensis, while the second axis represents the effect of livestock density and inorganic fertilizer use. Barley yield was positively associated with $F$. albida density, where the highest barley yield (class 3) was strongly related to a high F. albida density (HA), whereas low yield (class 1) was associated with a low F. albida density (LA). High barley yield was negatively associated with locations with $E$. camaldulensis domination (HE), while intermediate barley yield (class 2) was associated with intermediate $F$. albida tree density (MA) and with high fertilizer input (HF). Low inorganic fertilizer was positively associated with highest barley yield (class 3). However, livestock density did not show a clear relationship with barley yield.

The spatial distribution of LULC types and F. albida based-land use systems was clearly related (Fig. 7). The sparsely cultivated class (Scu) was associated with farms having a high density of $F$. albida and low dominance of
Table 2 Test of fixed effects on barley yield, total N, OM, available $\mathrm{P}$, soil moisture and soil $\mathrm{pH}$ for the 2005 field locations $(n=77)$ in Tigray, Ethiopia

Manag is land use system of Faidherbia albida (F. albida alone (AA), F. albida and livestock (AL) or F. albida and Eucalyptus (AE)); Dist is distance from the center of $F$. albida tree trunk

Num $D F$ is Numerator Degree of Freedom, Den DF is Denominator Degree of Freedom

\begin{tabular}{lllccr}
\hline \multirow{2}{*}{ Barley yield } & Source & Num DF & Den DF & Type III F & $P$-value \\
& Manag & 2 & 9.47 & 1.71 & 0.2316 \\
& Dist & 2 & 17.3 & 9.44 & 0.0017 \\
Total N & Dist*Manag & 4 & 17.4 & 6.58 & 0.0021 \\
& Manag & 2 & 10.3 & 0.76 & 0.4911 \\
& Dist & 2 & 210 & 0.18 & 0.8377 \\
OM & Dist*Manag & 4 & 210 & 3.22 & 0.0135 \\
& Manag & 2 & 7.86 & 2.23 & 0.1711 \\
& Dist & 2 & 212 & 3.48 & 0.0325 \\
Available P & Dist*Manag & 4 & 212 & 0.14 & 0.9692 \\
& Manag & 2 & 222 & 4.18 & 0.0164 \\
& Dist & 2 & 219 & 4.46 & 0.0127 \\
Moist & Dist*Manag & 4 & 219 & 4.99 & 0.0007 \\
& Manag & 2 & 8.21 & 1.84 & 0.2182 \\
& Dist & 2 & 17.1 & 18.83 & $<0.0001$ \\
pH & Dist*Manag & 4 & 17.1 & 34.41 & $<0.0001$ \\
& Manag & 2 & 13 & 1.60 & 0.2400 \\
& Dist & 2 & 0.69 & 0.5003 \\
& Dist*Manag & 4 & 215 & 0.66 & 0.6188 \\
\hline
\end{tabular}


Table 3 Mean estimates and standard error from mixed model analysis for barley yield, total N, organic matter (OM), available P, soil moisture and $\mathrm{pH}$ for the 2005 field locations $(n=77)$ in Tigray, Ethiopia

\begin{tabular}{|c|c|c|c|c|c|c|c|c|c|c|c|c|c|}
\hline \multirow[t]{2}{*}{ Manag } & \multirow[t]{2}{*}{ Dist (m) } & \multicolumn{2}{|c|}{ Barley Yield $\left(\mathrm{kg} \cdot \mathrm{ha}^{-1}\right)$} & \multicolumn{2}{|c|}{ Total N (\%) } & \multicolumn{2}{|c|}{ OM (\%) } & \multicolumn{2}{|c|}{ Available P (mg. $\mathrm{kg}^{-1}$ ) } & \multicolumn{2}{|c|}{ Soil Moisture (\%) } & \multicolumn{2}{|c|}{ Soil pH } \\
\hline & & Mean & SE & Mean & SE & Mean & SE & Mean & SE & Mean & SE & Mean & $\mathrm{SE}$ \\
\hline AA & 1 & 1396 & 82 & 0.15 & 0.02 & 2.13 & 0.22 & 20.09 & 3.81 & 9.8 & 0.14 & 6.43 & 0.32 \\
\hline AA & 25 & 992 & 82 & 0.14 & 0.02 & 1.89 & 0.22 & 17.87 & 3.81 & 9.0 & 0.14 & 6.45 & 0.32 \\
\hline AA & 50 & 940 & 82 & 0.12 & 0.02 & 1.78 & 0.22 & 14.75 & 3.81 & 8.4 & 0.14 & 6.44 & 0.32 \\
\hline $\mathrm{AL}$ & 1 & 1345 & 75 & 0.17 & 0.02 & 2.36 & 0.20 & 39.02 & 3.52 & 9.7 & 0.13 & 6.63 & 0.309 \\
\hline $\mathrm{AL}$ & 25 & 1024 & 75 & 0.14 & 0.02 & 2.29 & 0.20 & 19.15 & 3.52 & 8.8 & 0.13 & 7.38 & 0.309 \\
\hline $\mathrm{AL}$ & 50 & 881 & 75 & 0.14 & 0.02 & 2.01 & 0.20 & 17.15 & 3.52 & 8.2 & 0.13 & 6.66 & 0.30 \\
\hline $\mathrm{AE}$ & 1 & 1098 & 75 & 0.14 & 0.02 & 2.40 & 0.20 & 15.80 & 3.52 & 8.3 & 0.13 & 6.60 & 0.30 \\
\hline $\mathrm{AE}$ & 25 & 1249 & 75 & 0.16 & 0.02 & 2.36 & 0.20 & 22.58 & 3.52 & 9.0 & 0.13 & 6.61 & 0.30 \\
\hline $\mathrm{AE}$ & 50 & 1246 & 75 & 0.18 & 0.02 & 2.07 & 0.20 & 18.04 & 3.52 & 9.3 & 0.13 & 6.61 & 0.30 \\
\hline
\end{tabular}

Manag is land use system of Faidherbia albida (F.a albida alone (AA), F. albida and livestock (AL) or F. albida and Eucalyptus (AE)); Dist is distance from the center of $F$. albida tree trunk

E. camaldulensis, while the intensively cultivated areas (Icu) were characterized by low F. albida densities and higher $E$. camaldulensis presence.

Figure 8 describes the hypothetical consequences of F. albida tree removal from calculations based on our data. The overall yield benefit or added ecosystem service for the idealized sparsely cultivated land use system (high tree density) at T1 (34 F. albida trees) is shown as E3 (100\%) in Fig. 8. Removing trees from inside of the field at random until point T2 (16 F. albida trees) was reached, resulted in a reduction in yield benefit from $100 \%$ in $\mathrm{E} 3$ to $40 \%$ in E2, or $66 \mathrm{~kg} \mathrm{ha}^{-1}$ tree $^{-1}$. Further removal of trees down to trees just at the corners of the fields (T3: $4 F$. albida trees) and complete clearing took away less yield benefit, as the zone of influence of the trees became progressively lower.

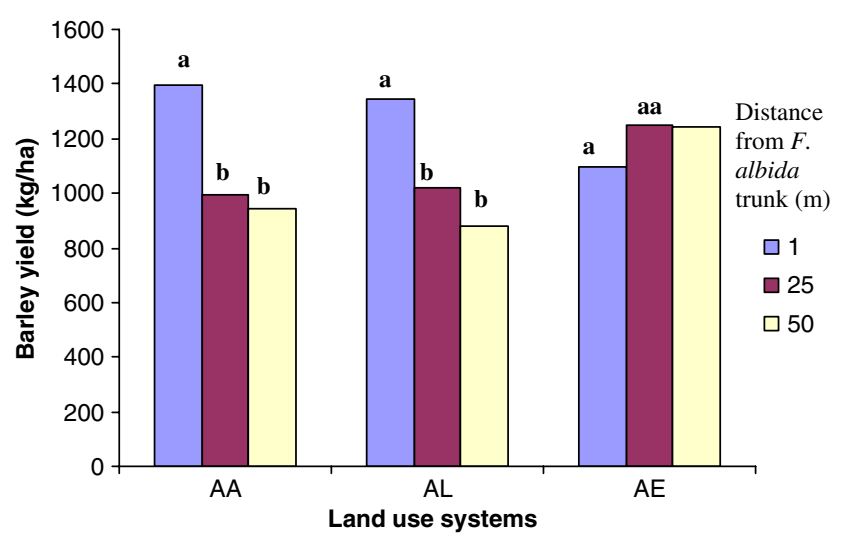

Note: Land use system (LUS) with the same letter are not significantly different.

Fig. 3 Mean $( \pm \mathrm{SE})$ barley yield $\left(\mathrm{kg} \cdot \mathrm{ha}^{-1}\right)$ at increasing distance from the centre of an Faidherbia albida trunk and for three land use system (F. albida only, F. albida and livestock, and F. albida and Eucalyptus) for 77 field locations sampled in 2005 in Tigray, Northern Ethiopia

\section{Discussion}

The study presented in this paper integrates field measurements and farm survey data to demonstrate the effect of different $F$. albida based land use systems on barley yield. For the AA and AL land use systems, significantly higher barley yield and soil moisture content were found close to the $F$. albida tree trunk compared to outside the canopy (Table 3 and Fig. 3). These effects are attributed to nitrogen fixation by $F$. albida (Rao et al. 1998) and nitrogen supply by shedding its leaves during the cropping season, thus having a reduced water demand during that season and by enhancing water holding capacity thereby reducing crop wilting during dry periods (Rhoades 1995). These results confirm the effect of $F$. albida on productivity found in other studies in Ethiopian smallholder farming systems. Poschen (1986), revealed a $56 \%$ increase in grain yields of combined maize (Zea mays L.) and sorghum (Sorghum bicolor L. Moench) crops under F. albida trees as compared to crop yields outside the tree canopy. Kamara and Haque (1992) investigated soil fertility in vertisols, and demonstrated that organic matter, $\mathrm{N}$, $\mathrm{P}$ and available water capacity (soil's capacity to hold water for use by plants) were higher under F. albida canopies than outside. Similar results were found in other African countries, including Niger (Vandenbeldt and Williams 1992; Kho et al. 2001; Payne et al. 1998) and Tanzania (Chamshama et al. 1998). These studies demonstrated that F. albida trees contributed to yield increases in sorghum, maize and millet and enhanced soil fertility, mainly levels of total nitrogen and available phosphorus. Clear differences in total N, soil organic matter and available $\mathrm{P}$ under and away from the canopy were also found in our study (Table 2) but variation in data precluded statistical significance. This may also be because of the large distance between sampling points $(1,25$ and $50 \mathrm{~m}$ away from an F. albida trunk) and collection of soil samples 
Table 4 Multiple regression (forward selection) of soil properties and their contribution to barley yield for each land use system in 2005 in Tigray, Northern Ethiopia

\begin{tabular}{lllrr}
\hline Land use system & Variable Entered & Partial R-Square & C $(\mathrm{p})$ & $\mathrm{F}$ value \\
\hline AA $(n=69)$ & Moisture & 0.1417 & 1.0597 & 11.06 \\
AL $(n=81)$ & Moisture & 0.1310 & 1.9932 & 0.0014 \\
& P & 0.0348 & 0.8287 & 0.0009 \\
\hline
\end{tabular}

Total N, OM, available P, soil Moisture content and $\mathrm{pH}$ were entered to the regression model but none of them was significant for the AE land use system

after crop harvest, as we did not have a chance to collect soil samples at the beginning of crop growth. In the AL land use system available $\mathrm{P}$ was much higher closer to the F. albida trunk, possibly due to the effect of manure from the livestock.

In contrast, results for the E. camaldulensis dominated land use system (AE) indicated that barley yields under $F$. albida in the vicinity of E. camaldulensis trees did not differ from those in the open field, indicating that the benefits of $F$. albida were offset by E. camaldulensis. On the contrary, an increasing trend in barley yield was observed with increasing distance from the $F$. albida trunk (Fig. 3). Also soil fertility parameters were affected in a different way from that in $\mathrm{AA}$ and $\mathrm{AL}$ systems. In the $\mathrm{AE}$ land use system, significantly lower total $\mathrm{N}$, available $\mathrm{P}$ and soil moisture were observed under the $F$. albida trunk than further away, whereas a higher OM-content was found closer to the F. albida trunk in the AE land use system. Crop yield comparison under and at a distance from sole E. camaldulensis tree canopies, without adjacent $F$. albida, was carried out in other studies. Asfaw and Ågren (2007) reported a higher organic $\mathrm{C}$ but lower available $\mathrm{P}$ and total $\mathrm{N}$ under a Eucalyptus tree canopy than outside the canopy. Malik and Sharma (1990) observed a decrease of $47 \%$ in mustard and $34 \%$ in wheat yields at 10 meter
Fig. 4 Overlay of field locations with Faidherbia albida trees with a 2005 LULC map and $\mathbf{b}$ elevation map for the subregion in Tigray, Northern Ethiopia

\section{(a)}

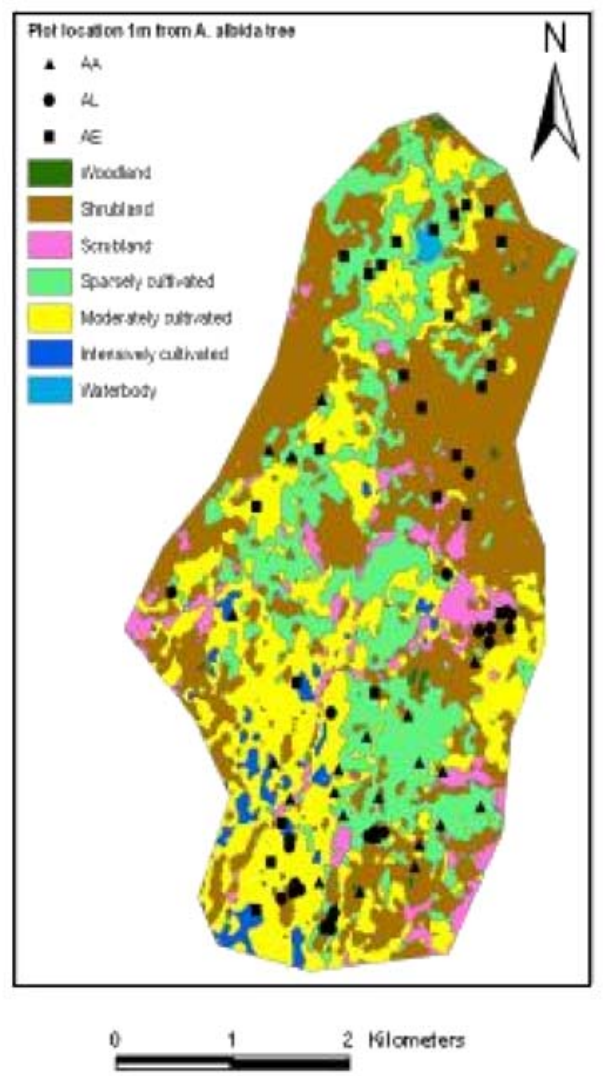

(b)

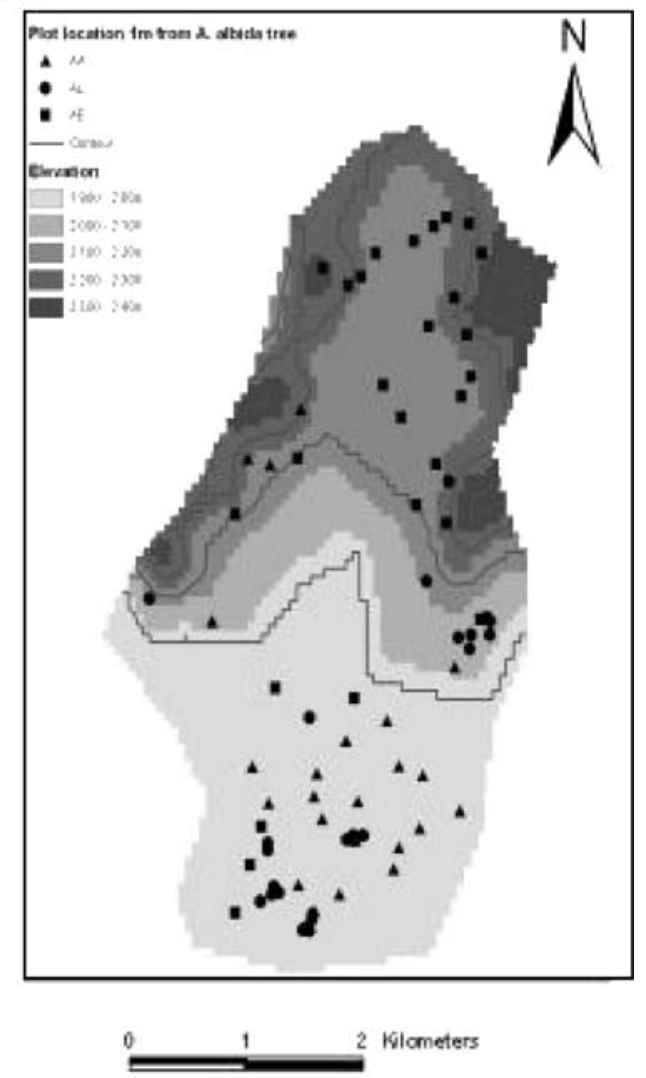

Note:

Land use system of Faidherbia albida alone (AA), F. albida and livestock (AL) and F. albida and Eucalyptus (AE). 


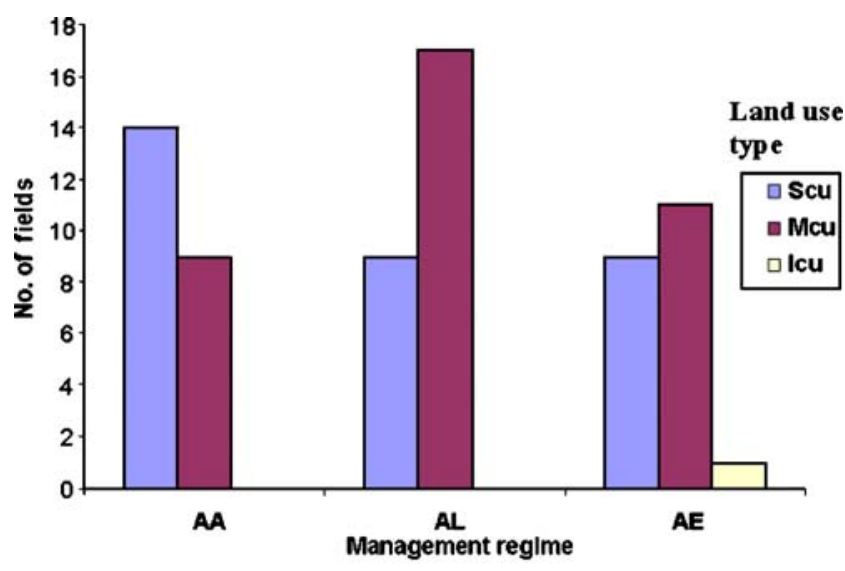

Note

Land use system of Faidherbia albida alone (AA), F. albida and livestock (AL) and F. albida and Eucalyptus (AE); Land use types: $\mathrm{Scu}=$ Sparsely cultivated; $\mathrm{Mcu}=$ Moderately cultivated; Icu = Intensively cultivated.

Fig. 5 Relation between agricultural land use types and land use system derived from field scale observations for 2005 in Tigray, Northern Ethiopia

distance from Eucalyptus tree strips. Singh and Kohli (1992) indicated that yield of chickpea, lentil, wheat and cauliflower decreased by more than a half in a 12-m-wide strip adjacent to Eucalyptus shelterbelts. Similarly, barley yield under the AE land use system in our study decreased as the distance to $F$. albida next to a $E$. camaldulensis tree decreased. This effect can be attributed to the high nutrient and water demand of Eucalyptus trees (Sanginga and Swift 1992) growing adjacent to $F$. albida in the AE land use system. Moreover, allelopathic substances released from leaves or litter of Eucalyptus (Poore and Fries 1985) may also hinder growth of a barley crop. A higher OM-content was observed under $F$. albida canopy than further away in the AE land use system (Table 3). The higher OM under the canopy of the AE land use system may be related to the slow decomposition rate of Eucalyptus litter (Adams and Attiwill 1986). Unlike the AA and AL land use systems, lower available P was observed at a decreasing distance from the center of $F$. albida trunk for the AE land use system. The fact that Eucalyptus trees reduce vesicular-arbuscular mycorrhizal (VAM) fungal growth and reduce available $P$ for plant uptake (Siqueira et al. 1991) may contribute to lower available $\mathrm{P}$ in the $\mathrm{AE}$ land use system. Moreover, lower soil moisture was observed as distance from the center of $F$. albida trunk decreased in the AE land use system, possibly because of negative effects of Eucalyptus on moisture availability for crops growing close to the tree (Sanginga and Swift 1992). Other studies in Ethiopia indicated decreasing crop output because of the negative hydrological impacts of Eucalyptus trees growing close to crops (Malik and Sharma 1990; Saxena 1991; Calder et al. 1993). Apparently, our choice of systems, with $F$. albida and E. camaldulensis growing in mixed stands dampened negative effects of pure $E$. camaldulensis stands. This suggests there may be room for optimization of E. camaldulensis deployment.

Combination of GIS-based land use classification and field measurement results revealed a relationship between land use types and land use systems (Fig. 4a and 5). Taking into account any inaccuracies in land use classifications (Hadgu et al. 2008a) and GPS measurements, sparsely cultivated land (also called agroforestry land use type) and moderately cultivated land use types were mainly associated with the AA and AL land use system, respectively. The yield increase in the AA and AL land use system could therefore be attributed to the presence of more trees and shrubs, especially with more F. albida trees, in and around agricultural fields of the sparsely cultivated (agroforestry) land use type (Hadgu et al. 2008b). Although the surface area occupied by intensively cultivated land was relatively low compared to surface area occupied by sparsely and moderately cultivated lands, the AE land use system, associated with low barley yield and soil fertility, was mainly observed in the intensively cultivated landscape.

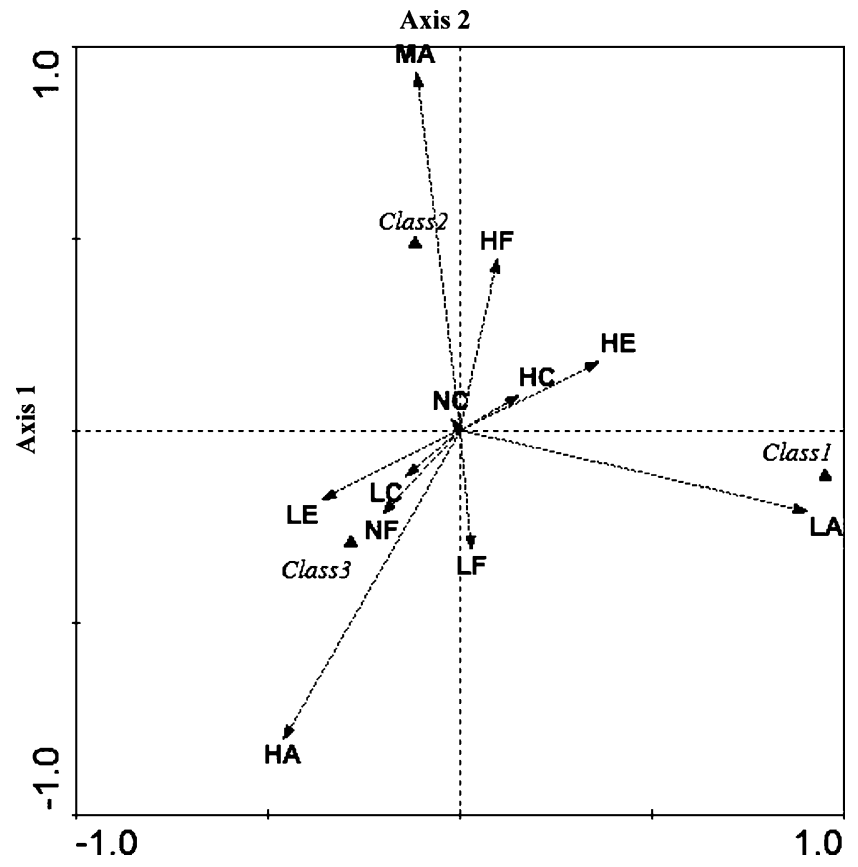

Fig. 6 Ordination diagram (Canonical correspondence analysis, CCA) of response variable barley yield and environmental variables represented with triangles and arrows respectively. The length of the arrow and its closeness to the CCA axes is a measure of its strength. Response variables are barley yield of Class $1\left(<500 \mathrm{~kg} \cdot \mathrm{ha}^{-1}\right)$, Class 2 $\left(500-1000 \mathrm{~kg} \cdot \mathrm{ha}^{-1}\right)$ and Class $3\left(>1000 \mathrm{~kg} \cdot \mathrm{ha}^{-1}\right)$. Explanatory categories are: no fertilizer (NF; $0 \mathrm{~kg} \mathrm{~N} \cdot \mathrm{ha}^{-1}$ ), low fertilizer use (LF; 1-25 kg N.ha ${ }^{-1}$ ), high fertilizer use (HF; $>25 \mathrm{~kg} \mathrm{~N} \mathrm{ha}^{-1}$ ), no livestock (NC; no cattle.farm ${ }^{-1}$ ), low livestock (LC; 1-2 cattle.farm ${ }^{-1}$ ), high livestock $\left(\mathrm{HC} ;>2\right.$ cattle.farm $^{-1}$ ), low Eucalyptus farm characteristics (LE; low Eucalyptus.farm ${ }^{-1}$ ), Eucalyptus dominated farm characteristics (HE; high Eucalyptus farm ${ }^{-1}$ ), low Faidherbia albida density (LA; low Faidherbia albida farm $^{-1}$ ), medium Faidherbia albida density (MA; medium Faidherbia albida. farm ${ }^{-1}$ ) and high Faidherbia albida density (HA; high Faidherbia albida. farm $^{-1}$ ) 


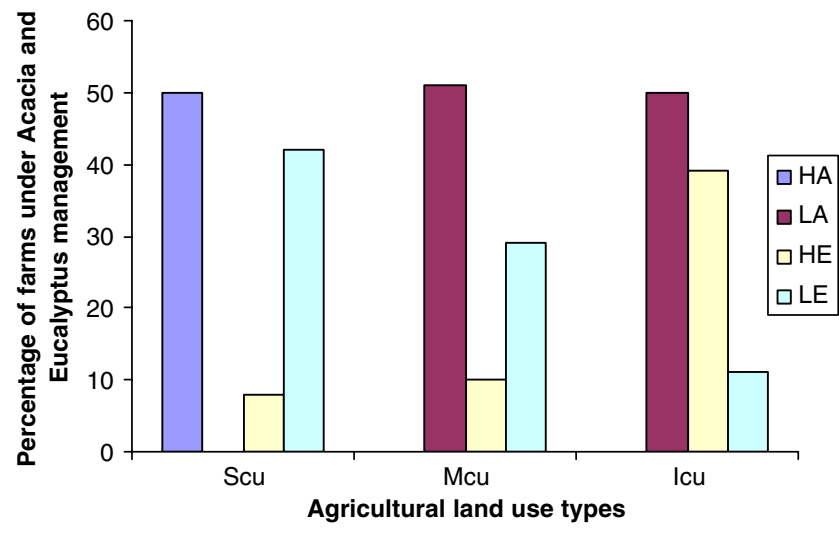

Note: Scu $=$ Sparsely cultivated; $\mathrm{Mcu}=$ Moderately cultivated; Icu = Intensively cultivated; HA = High dominance of Faidherbia albida; LA = Low dominance of $\mathrm{F}$. albida , $\mathrm{HE}=$ High dominance of Eucalyptus and $\mathrm{LE}=$ Low dominance of Eucalyptus.

Fig. 7 Faidherbia albida and Eucalyptus tree farm characteristics in relation to agricultural land use types at regional scale in Tigray, Northern Ethiopia

This implies that fewer trees/shrubs are present in the $\mathrm{AE}$ land use system as compared to the AA and AL land use system. The association of the intensively cultivated landscape and $\mathrm{AE}$ land use system may be attributed to the plantation of Eucalyptus trees and irrigation practices which are common in areas close to micro-dams located in the northern part of the sub-region (Fig.1b). Moreover, farmers in the $\mathrm{AE}$ land use system practise irrigation farming, use inorganic fertilizer and plant $E$. camaldulensis in and around their agricultural fields to raise their farm income mainly because of their proximity to the microdam. In contrast, traditional farming practices (agroforestry systems) without application of inorganic fertilizer are still practised in fields with the AA and AL land use systems.

The farm survey data confirmed the results found at the field scale. From the farm survey data it was apparent that higher barley yield (Class 3) was strongly associated with high F. albida tree dominance (Fig. 6) which in turn was strongly associated with sparsely cultivated land use type (Fig. 7). High yield was also associated with low $E$. camaldulensis density and with no or low fertilizer inputs. Low barley yield (Class 1) was observed in farms with low F. albida presence. These results could be associated with land use intensification policies, which emphasize use of fertilizer and often lead to land clearing. There are different explanations for the relatively low yields in intensively cultivated land. One is that the intensification technology is not used properly. Another explanation is that the fertilizer levels used are not compensating for the loss of $F$. albida mediated yield benefits although we do not have data on the exact time of fertilizer application.
The results of the regional farm surveys showed much more clearly than the field data the relation between low $F$. albida densities and Mcu and Icu land use types (Fig. 7). Also, they demonstrate that there is an intensification trajectory from Scu to $\mathrm{Mcu}$ and Icu which is characterized by fewer $F$. albida and more E. camaldulensis trees. This can be partly explained by the nature of the different datasets from field and regional scales. The dataset from the field was collected from less intensely cultivated parts than the farm survey dataset. Similar to our observations at field scale (Fig. 5), also at regional scale, the sparsely cultivated land use type was association with high $F$. albida densities whereas the intensively cultivated land use type was associated with high E. camaldulensis densities (Fig. 7).

A longitudinal analysis in the same study region across 41 years by Hadgu et al. (2008a) indicated that intensively cultivated and moderately cultivated land use types increased at the expense of declining sparsely cultivated land use type. The graphical analysis (Fig. 8) also revealed that the highest ecosystem loss was attributed to cutting of trees from sparsely cultivated land use type (I in Fig. 8) followed by cutting of trees from moderately (II in Fig. 8) and intensively cultivated (III in Fig. 8) land use types.

\section{Conclusions}

This study integrates field and regional scales to explore the implication of a $F$. albida land use system and land use types on productivity, in this case barley yield. The results of this study revealed increased barley yield and soil

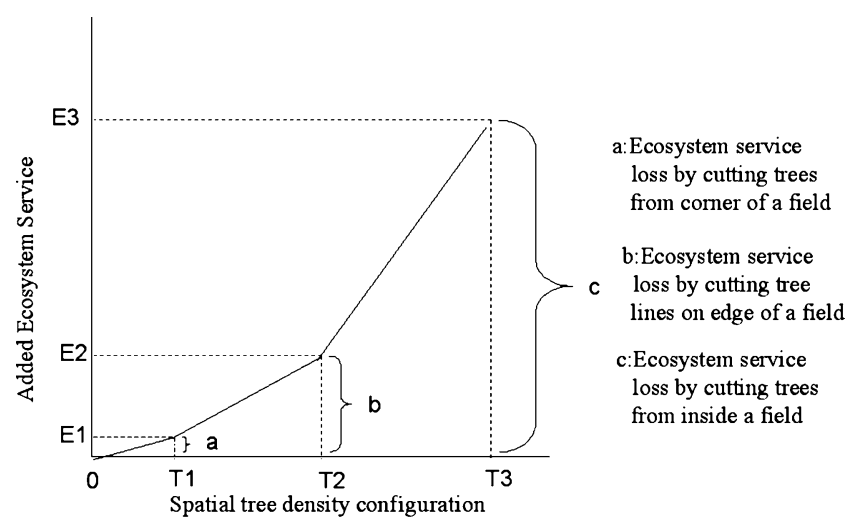

Note: At T1 $F$. albida tree density is 4 per ha.

At T2 $F$. albida tree density is 16 per ha.

At T3 $F$. albida tree density is 34 per ha.

Fig. 8 Theoretical model for added ecosystem service of increasing Faidherbia albida tree density on barley yield at farm level where E1, E2 and E3 refer to increasing barley yield levels for three spatial density configurations of Faidherbia albida on corner, edge and within agricultural fields 
fertility as the distance to an F. albida trunk decreased in the AA and AL land use system. On the contrary, barley yield and soil fertility showed a decreasing trend as the distance to an F. albida trunk decreased in the AE land use system. The study also demonstrated that higher ecosystem service, in terms of barley yield, can be rendered by having more F. albida trees within a field than only at the edge or corner of a field. Higher ecosystem service can also be gained from sparsely cultivated land use types than intensively and moderately cultivated land use types.

This study suggests that productivity of crops and soils can be increased by appropriate use of local biodiversity resources, for example, $F$. albida trees. Our study does not lead to firm conclusions for policy directions but raises the question whether current intensification strategies are sufficiently taking local natural resources into account. Sonneveld and Keyzer (2003) predicted that agricultural lands will expand and land use will intensify to increase food production in Ethiopia. The human population in Ethiopia is expected to double by 2030, at a growth rate of $2.7 \%$ annually, as compared to the present population (Sonneveld and Keyzer 2003; CSA 2004). Food demand is expected to grow even faster, $3.6 \%$ annually (Sonneveld and Keyzer 2003; UN Millennium Project 2005) because of the increase in population and changes in diet associated with urbanization. Policy makers and land use planners, as well as stakeholders in agricultural production and nature conservation, need to reconcile the differences in opinion on the basis of scientific evidence about the complementarities of local natural resource conservation and agricultural productivity, in order to accommodate the continuing and growing demand for agricultural products and the need for ecosystem services such as soil fertility enhancement, protection against soil erosion, water retention, flood control, pollination and pest control (Thrupp 2000; Scherr and McNeely 2008). Land use planners and decision makers should integrate locally available resources in planning and implementing rural developments at different spatial scales: field, farm and region. Local farmers should be involved in land use planning by sharing their knowledge of traditional farming practices and contributing to the protection and restoration of natural habitats, for example by raising their ecological, economic and social awareness.

Acknowledgements Financial support was provided by an International Institute of Tropical Agriculture (IITA)-Lukas Brader Fellowship and a Netherlands Fellowship Programme (NUFFIC) to the first author. We thank IITA for providing the IITA- Lukas Brader Fellowship. We also thank Mr B. Oyewole, for logistic support, and Dr Morag Ferguson and Dr Michael Pillay, for being IITA supervisors.

Open Access This article is distributed under the terms of the Creative Commons Attribution Noncommercial License which permits any noncommercial use, distribution, and reproduction in any medium, provided the original author(s) and source are credited.

\section{References}

Adams MA, Attiwill PM (1986) Nutrient cycling and nitrogen mineralization in Eucalypt forests of southeastern Australia. II. Indices of nitrogen mineralization. Plant Soil 92:341-362

Akonde TP, Leihner DE, Steinmuller N (1996) Alley cropping on an Ultisol in subhumid Benin. Part 1. Longterm effect on maize, cassava and tree productivity. Agrofor Syst 34:1-12

Asfaw Z, Ågren GI (2007) Farmers' local knowledge and topsoil properties of agroforestry practices in Sidama, Southern Ethiopia. Agrofor Syst 71:35-48

Calder IR, Hall RK, Prasanna KT (1993) Hydrological impact of Eucalyptus plantation in India. J Hydrol 150:635-648

Caldwell MM, Richards JH (1989) Hydraulic lift: water efflux from upper roots improves effectiveness of water uptake by roots. Oecologia 75:1-5

Cannell MGR, Van Noordwijk M, Ong CK (1996) The central agroforestry hypothesis: the trees must acquire resources that the crop would not otherwise acquire. Agrofor Syst 34:27-31

Chamshama SAO, Mugasha AG, Kløvstad A, Haveraaen O, Maliondo SMS (1998) Growth and yield of maize alley cropped with Leucaena leucocephala and Faidherbia albidain Morogoro. Tanzania Agrofor Syst 40:215-225

Costanza R, Dárge R, De Groot RS, Farber S, Grasso M, Hannon B et al (1997) The value of the world's ecosystem services and natural capital. Nature 387:253-260

CSA (2004) Statistical Abstracts. Ethiopian Central Statistical Authority (CSA), Addis Ababa

Daily GC (1997) Introduction: what are ecosystem services? In: Daily GC (ed) Nature's services: societal dependence on natural ecosystems. Island, Washington, DC, pp 1-10

Dawson JF (1993) Hydraulic lift and water use by plants: implications for water balance, performance and plant-plant interactions. Oecologia 95:565-574

Dejene A (2003) integrated natural resources management to enhance food security: the case for community-based approaches in Ethiopia. Environment and Natural Resources Working Paper No. 16. Rome: FAO.

Deurloo HA, Haileselassie T (1994) Rehabilitation of degraded and degrading areas of Tigray, Ethiopia, survey on farm practices based on local knowledge. Wageningen Agricultural University, Wageningen

Feoli E, Vuerich LG, Woldu Z (2002) Processes of environmental degradation and opportunities for rehabilitation in Adwa, Northern Ethiopia. Landscape Ecol 17:315-325

García-Barrios L (2003) Plant-plant interactions in tropical agriculture. In: Vandermeer J (ed) Tropical agroecosystems. CRC, NewYork, pp 1-58

García-Barrios L, Ong CK (2004) Ecological interactions, management lessons and design tools in tropical agroforestry systems. Agrofor Syst 61:221-236

Goldberg D (1990) Components of resource competition in plant communities. In: Grace JB, Tilman D (eds) Perspectives on plant competition. Academic, New York, pp 27-49

Hadgu KM, Kooistra L, Rossing WA, Van Bruggen AHC (2008a) Detection of land use/ land cover changes by remote sensing and associated drivers for the period 1964-2005 in the highlands of Tigray, Ethiopia. J Environ Manag (Submitted)

Hadgu KM, Epema GF, Van Bruggen AHC (2008b) Biodiversity and Sustainability in Agricultural landscapes in Tigray, Northern Ethiopia. Int J Agric Sustain (Submitted)

Hadgu KM, Rossing WA, Kooistra L, Van Bruggen AHC (2009) Spatial variation in biodiversity, soil degradation and productivity in agricultural landscapes in the highlands of Tigray, northern Ethiopia. Food Sec 1:83-97

Hunter AF, Aarssen LW (1988) Plants helping plants. Biosci 38:34-40 
Hurni H (1993) Land degradation, famine and land resource scenarios in Ethiopia. In: Pimentel D (ed) World soil erosion and conservation (pp 27-61). Cambridge University Press, Cambridge

IAASTD (2008) Synthesis Report of IAASTD. International Assessment of Agricultural Science and Technology for Development (IAASTD). Island, Washington, DC

IAC (2004) Realizing the promise and potential of African agriculture: science and technology strategies for improving agricultural productivity and food security in Africa. InterAcademy Council, Amsterdam

Kamara CS, Haque I (1992) Faidherbia albida and its effects on Ethiopian highland Vertisols. Agrofor Syst 18:17-29

Kho RM, Yacouba B, Yayé M, Katkoré B, Moussa A, Iktam A, Mayaki A (2001) Separating the effects of trees on crops: the case of Faidherbia albida and millet in Niger. Agrofor Syst 52:219-238

Liebman M, Gallandt ER (1997) Many little hammers: ecology management of crop-weed interactions. In: Jackson LE (ed) Ecology in agriculture. Academic, New York, pp 291-343

Malik RS, Sharma SK (1990) Moisture extraction and crop yield as a function of distance in a row of eucalyptus tereticornis. Agrofor Syst 12:187-195

MEA (2003) Ecosystems and human well-being a framework for assessment. In: Alcamo J, Bennett EM (eds) Millennium ecosystem assessment. Island, Washington, DC

MEA (2005) Ecosystems and human well-being: current state and trends. In: Hassan R, Scholes R (eds) Millennium ecosystem assessment. Island, Washington, DC

Miller AW, Pallardy SG (2001) Resource competition across the croptree interface in a maize-silver maple temperate alley cropping stand in Missouri. Agrofor Syst 53:247-259

MoNRDEP (1990) Soil Analysis Laboratory Manual. Ministry of Natural Resources Development and Environmental Protection (MoNRDEP), Addis Ababa: MoNRDEP

Odhiambo HO, Ong CK, Deans JD, Wilson J, Khan AAH, Sprent JI (2001) Roots, soil water and crop yield: tree crop interactions in a semi-arid agroforestry systems in Kenya. Plant Soil 235:221233

Ong CK (1995) The 'dark side' of intercropping: manipulation of soil resources. In: Sinoquent H, Cruz P (eds) Ecophysiology of tropical intercropping. Institute National de la Recherche Agronomique, Paris, pp 45-65

Ong CK, Leakey RRB (1999) Why tree-crop interactions in agroforestry appear at odds with tree-grass interactions in tropical savannahs. Agrofor Syst 45:109-129

Ong CK, Black CR, Marshall FM, Corlett JE (1996) Principles of resource capture and utilization of light and water. In: Ong CK, Huxley P (eds) Tree-crop interactions: a physiological approach. CAB International, Wallingford, pp 73-158

Paoletti MG, Pimentel D, Stinneff BR, Stinneff D (1992) Agroecosystem biodiversity: matching prod'uction and conservation biology. Agric Ecosyst Environ 40:3-23

Payne WA, Williams JH, Maì Moussa KA, Stern RD (1998) Crop diversification in the sahel through use of environmental changes near Faidherbia albida (Del.) A. Chev. Crop Sci 38:1585-1591

Poore MED, Fries C (1985) The ecological effects of eucalyptus. Forestry Paper No. 59. FAO, Rome

Poschen P (1986) An evaluation of the Acacia albida-based agroforestry practices in the Hararghe highlands of Eastern Ethiopia. Agrofor Syst 4:129-143

Radersma S, Grierson PF (2004) Phosphorus mobilization in agroforestry: organic anions, phosphatase activity and phosphorus fractions in the rhizosphere. Plant Soil 259:209-219

Radersma S, Lusiana B, Noordwijk MV (2004) Simulation of soil drying induced phosphorus deficiency and phosphorus mobilization as determinants of maize growth near tree lines on Ferralsol. Field Crops Res 91:171-184
Rao MR, Mathuva MN (2000) Legumes for improving maize yields and income in semi-arid Kenya. Agric Ecosyst Environ 78:123-137

Rao MR, Nair PKR, Ong CK (1998) Biophysical interactions in tropical agroforestry systems. Agrofor Syst 38:3-50

Rhoades CC (1995) Seasonal pattern of nitrogen mineralization and soil moisture beneath Faidherbia albida (syn Acacia albida) in central Malawi. Agrofor Syst 29:133-145

Rhoades CC (1997) Single-tree influences on soil properties in agroforestry: lessons from natural forest and savanna ecosystems. Agrofor Syst 35:71-94

Sachs JD, McArthur JW (2005) The millennium project: a plan for meeting the millennium development goals. Lancet 365:347-353

Sanchez PA (2002) Soil fertility and hunger in Africa. Sci. 295:20192020

Sanginga N, Swift MJ (1992) Nutritional effects of Eucalyptus litter on the growth of maize (Zea mays). Agric Ecosyst Environ 41:55-65

Sarraute JL, Vonder OW (1994) Rehabilitation of degraded and degrading areas of Tigray, Ethiopia: landsurface, landcover and change detection classifications based on remote sensing. Wageningen Agricultural University, Wageningen

SAS (1999) SAS/STAT user's manual, vol 1. SAS Institute Inc, Cary

Saxena NC (1991) Crop losses and their economic implications due to growing of eucalyptus on field bunds - a pilot study. Agrofor Syst 16:231-245

Scherr SJ, McNeely JA (2008) Biodiversity conservation and agricultural sustainability: towards a new paradigm of 'ecoagriculture' landscapes. Phil Trans R Soc B 363:477-494

Shiferaw B, Holden ST (2000) Policy instruments for sustainable land management: the case of highland smallholders in Ethiopia. Agric Econ 22:217-232

Singh D, Kohli RK (1992) Impact of Eucalyptus tereticornis Sm. shelterbelts on crops. Agrofor Syst 20:253-266

Siqueira JO, Nair MG, Hammerschmidt R, Safir GR (1991) Significance of phenolic compounds in plant-soil-microbial systems. Crit Rev Plant Sci 10:63-121

Smith DM, Jackson NA, Roberts JM, Ong CK (1999) Root distributions in a Grevillea robusta - maize agroforestry system in semi-arid Kenya. Plant Soil 211:91-205

Sonneveld BGJS, Keyzer MA (2003) Land under pressure: soil conservation concerns and opportunities for Ethiopia. Land Degrad Develop 14:5-23

Tekalign T, Haque I, Aduayi EA (1991) Soil, plant, water, fertilizer, animal manure and compost analysis. Plant Sciences Division Working Document No. B13. Addis Ababa: International Livestock Centre for Africa (ILCA)

Ter Braak CJF, Smilauer P (2002) CANOCO reference manual and CanoDraw for windows user's guide: software for canonical community ordination (version 4.5). Microcomputer Power, New York

Thrupp LA (2000) Linking agricultural biodiversity and food security: the valuable role of agrobiodiversity for sustainable agriculture. Int Aff 76:265-281

UN Millennium Project (2005) Investing in development: a practical plan to achieve the millennium development goals. Earthscan, New York

Vandenbeldt RJ, Williams JH (1992) The effect of soil surface temperature on the growth of millet in relation to the effect of Faidherbia albida trees. Agric Forest Meteorol 60:93-100

Worede M (1991) An Ethiopian perspective on conservation and utilization of plant genetic resources. In: Engels JMM, Hawkes JG, Worede M (eds) Plant genetic resources of Ethiopia. Cambridge University Press, Cambridge, pp 3-19

Worede M (1997) Ethiopian in situ conservation. In: Maxted N, Fordlloyd BV, Hawkes JG (eds) Plant genetic conservation: the in situ approach. Chapman and Hall, London, pp 290-301 


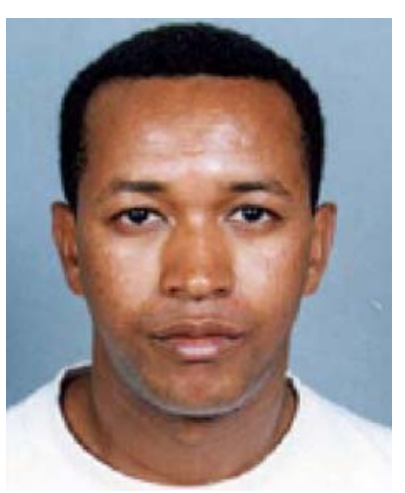

Kiros M. Hadgu obtained his BSc degree in Dryland Agriculture and Natural Resources from Mekelle University, Ethiopia. His $\mathrm{MSc}$ and $\mathrm{PhD}$, he received from Wageningen University in the Netherlands. Currently, he is working as lecturer at Mekelle University. His research interests are in the field of land use planning and watershed management using geo-information technology and remote sensing.

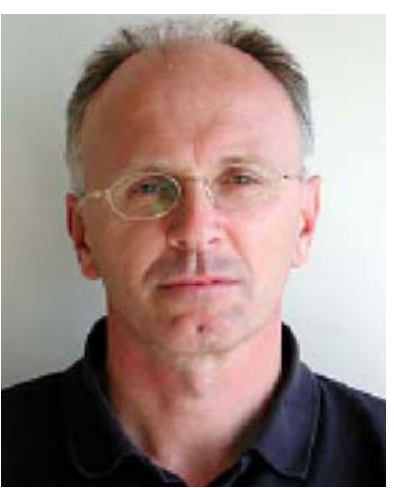

Walter A. H. Rossing obtained his $\mathrm{MSc}$ and $\mathrm{PhD}$ degrees in Theoretical Production Ecology from Wageningen University, the Netherlands. He currently is Associate Professor at Wageningen University. His research focuses on model-based design and analysis of organic and low-input farming systems, multifunctional agriculture and landscape design.

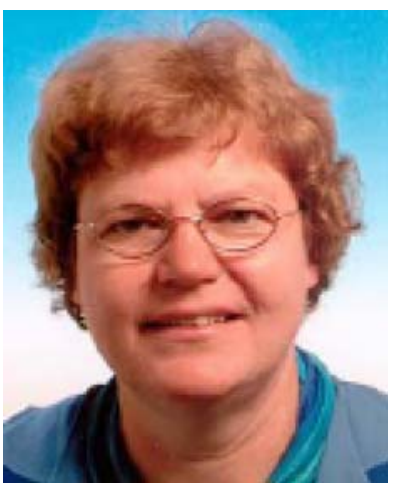

Ariena H. C. van Bruggen obtained her MSc degree fromWageningen University and her $\mathrm{PhD}$ degree in Plant Pathology from Cornell University at Ithaca, New York, USA. She worked as Professor in Plant Pathology at UC Davis in California, USA, and is currently Professor of Biological Farming Systems at Wageningen University. Her research focuses on detection of ecological principles and patterns underlying the functioning of durable and organic farming systems, and soil and ecosystem health. 